\title{
Effect of Heating Rate on Microstructural Developments in Cold Heading Quality Steel used for Automotive Applications
}

\author{
SHAHID HUSSAIN ABRO*, ALI DAD CHANDIO*, AND UMAIR AFTAB** \\ RECEIVED ON 18.01.2017 ACCEPTED ON 29.05.2017 \\ ABSTRACT
}

\begin{abstract}
CHQ (Cold Heading Quality) steels are assumed to be non-heat treatable so strengthened by cold forming which is a quick and mass production makes it low cost manufacturing process. In this study, microstructure and phase transformation in steels is a fundamental aspect of governing the properties. A large number of studies are dedicated on the subject phase transformations owing to availability of several commercial steel grades. Due to several grades of steels commercially available shows differently behavior so it is hard to conclude that phase transformation is universally understood completely. In this study the influence of heating rate on the development of microstructure of CHQ steel has been studied thoroughly by using different heating techniques.For characterization, optical microscope connected with high resolution camera and SEM (Scanning Electron Microscope) was utilized to interpret the microstructural results. In addition, heat treatment methods have been utilized as to vary the microstructure in the steel under experimentation. It was found that heating rate could have major effect on phase transformation of CHQ steel (under study). Rate of heating enhances the austenite development kinetics with respect to dwell time and such austenite has been changed to martensite upon cooling. In addition, heating rate also promotes nucleation sites for the formation of austenite phase of CHQ steel.
\end{abstract}

Key Words: Austenite Formation, Cold Heading Quality Steel, Nucleation and Heating Rate.

\section{INTRODUCTION}

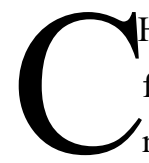
HQ steels are commonly known as raw materials for producing different small parts and are also non-heat treatable and are widely used in different applications in automotive, aircrafts, electrical power plants and construction etc.[1-3]. Increasing hardness either by rapid cooling after heat treatment or by cold forming during the process are main sources applied to achieve the desired strength[4]. Forming of martensite increases the hardness in steels, amount of martensite phase depends on amount of austenite formation [5-6],consequently rate of heating plays the important role in forming of austenite volume fraction thus heating rate is important step to design a microstructure[7]. During the process of cold heading a blank steel sheet or rod is used to produce the different parts by applying the external force through different kinds of dies and tools. Obviously, the original volume of that steel is not changed but the strength of those steel components after the process is improved to a certain level. [8-9].Conventional and rapid heating rates are applied in this work to study

Authors E-Mail: (engrabro@neduet.edu.pk, alidad_24@hotmail.com, umair.aftab@faculty.muet.edu.pk)

* Department of Materials Engineering, NED University of Engineering \& Technology, Karachi.

** Department of Metallurgy \& Materials Engineering, Mehran University of Engineering \& Technology, Jamshoro.

This is an open access article published by Mehran University Research Journal of Engineering and Technology, Jamshoro under the CC by 4.0 International License. 
the effect on austenite formation. Box furnace was used as and $10^{\circ} \mathrm{C} / \mathrm{min}$ rate of heating is applied to the experimental steel and lead bath furnace was applied as a rapid heating source.

\section{EXPERIMENTAL PROCEDURE}

To observe and study the effect of high heating rate the following cycle were used as shown in Fig. 1(a-b).

Experimental CHQ steel was cut into $10 \mathrm{~mm}$ equal pieces by using the hacksaw cutter. These samples were then wrapped with a steel wire and then preheated for 5 minutes. After preheating the samples were then inserted to lead bath furnace. Lead bath furnace was set down to the $800 \mathrm{C}$, samples were then holding in the cyanide filled lead bath for 10 and 60 seconds, respectively. The process of up-quenching in the lead bath was performed; [10], heat treatment as well as tempering itself was performed simultaneously. The set of other samples were then put in the box furnace and heating rate was set upto $20 \mathrm{C} /$ minute. The samples were then hold for 1 hour in the box and then quenched in the water.

The heat treated samples both in lead bath and box furnace were then brought into metallography step [112]. Conventional grinding and polishing were applied

FIG. 1(a). CONVENTIONAL HEAT TREATMENT CYCLE SLOW HEATING

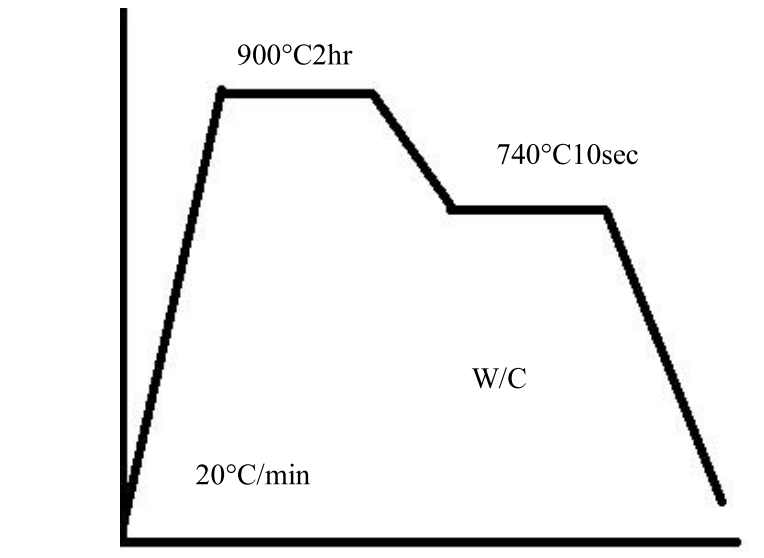

and then polished with a diamond paste on the polishing cloth as final step [13-14], the surface of the all samples was showing the mirror image. The polished samples were then bringing into Lepera etching solution to see the prior austenite grain size under the halogen light in the metallurgical microscope [15-16]. The optical micrographs as shown in Fig. 2 are taken from lead bath furnace, rapidly heated. Upon observation it seems that polygonal ferrite is decorated around the pearlite area. This polygonal ferrite is known to be pre-eutectoid ferrite [17], which is strongly bonded around the pearlite colony. The favorable nucleation sites for austenite formation in the rapidly heated steel are mostly pearlite areas as indicated by the arrow in picture 2 . The reason behind this nucleation is the smallest diffusion distances and carbon source is nearest in the form of cementite plates [18-19].

Furthermore, it is strongly observed that even a very short holding time of 10 seconds in the inter-critical temperature of $740^{\circ} \mathrm{C}$, austenite formation has been stimulated. Increasing the rate of heating promotes the nucleation of austenite from the cementite plates available in the pearlite areas [20]. After observing the microstructure taken by optical microscopy under ordinary light the samples were investigated by powerful SEM as shown in Fig. 3 .

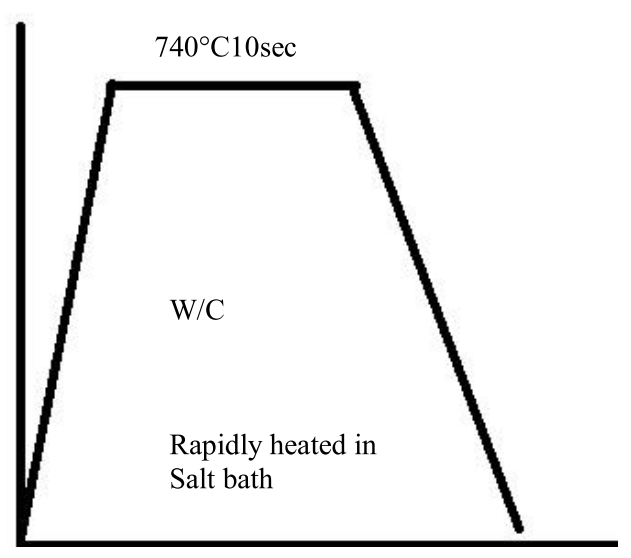

FIG. 1(b). LEAD BATH RAPID HEATING RATE 
Heating rate has a vital role and it has consequently effects upon phase transformation in cold heading quality steel [21-22]. The scanning electron micrographs as shown in Fig. 3 further indicates that the cementite plates in the pearlite colony slowly start to dissolve by forming the austenite phase in the territory of pearlite. However, there is no complete dissolution due to shortest time of holding; this may influence the end mechanical properties.

To observe the effect of rapid heating on phase transformation in the cold heading quality steel the conventional heating rate in the box furnace at a rate of $20 \mathrm{C} /$ minutes were also observed under the light microscopy as shown in Fig. 4.
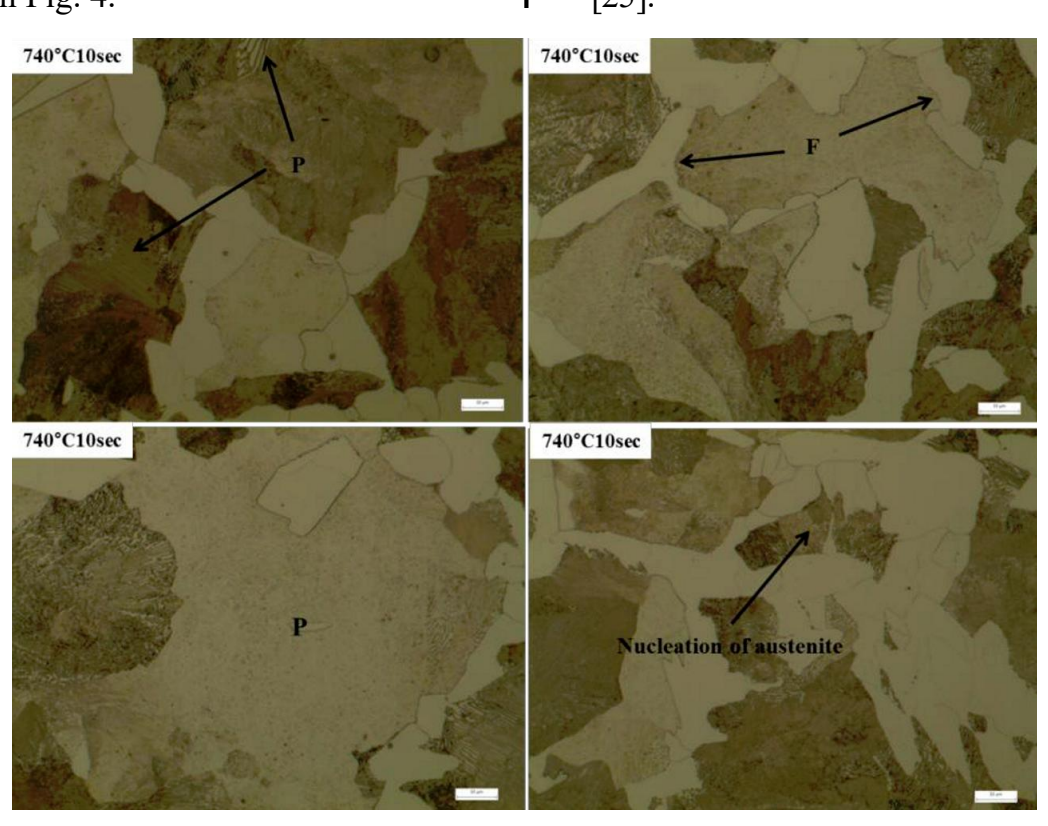

FIG. 2. OPTICAL MICROGRAPHS FROM LEAD BATH FURNACE AT $740^{\circ} \mathrm{C}$ FOR 10 SECOND HOLDING TIME
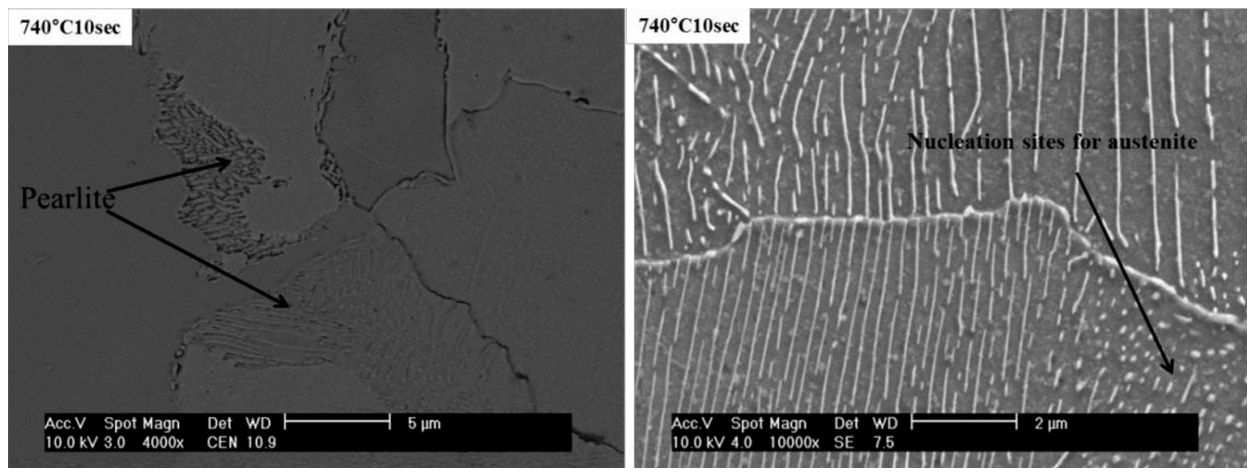

FIG. 3. SEM MICROGRAPHS OF RAPIDLY HEATED IN LEAD BATH FURNACE AT $740^{\circ} \mathrm{C}$ FOR 10 SECCOND

As compare to rapidly heated samples in the lead bath, the austenite nucleation is not clearer in the slowly heated samples. Even a higher holding time in the box furnace about one hour does not support the nucleation of austenite. Higher heating rate promote the productivity and also there is no opportunity for recrystallization due to shorter time during rapid heating [23-24]. The SEM micrographs in the slowly heated samples were also collected as shown in Fig. 5.

Rapidly heated steel samples showed the dissolving of cementite plates but slowly heated steel samples as shown in Fig. 5 does not show such indications $[25]$.

Mehran University Research Journal of Engineering \& Technology, Volume 37, No. 3, July, 2018 [p-ISSN: 0254-7821, e-ISSN: 2413-7219] 


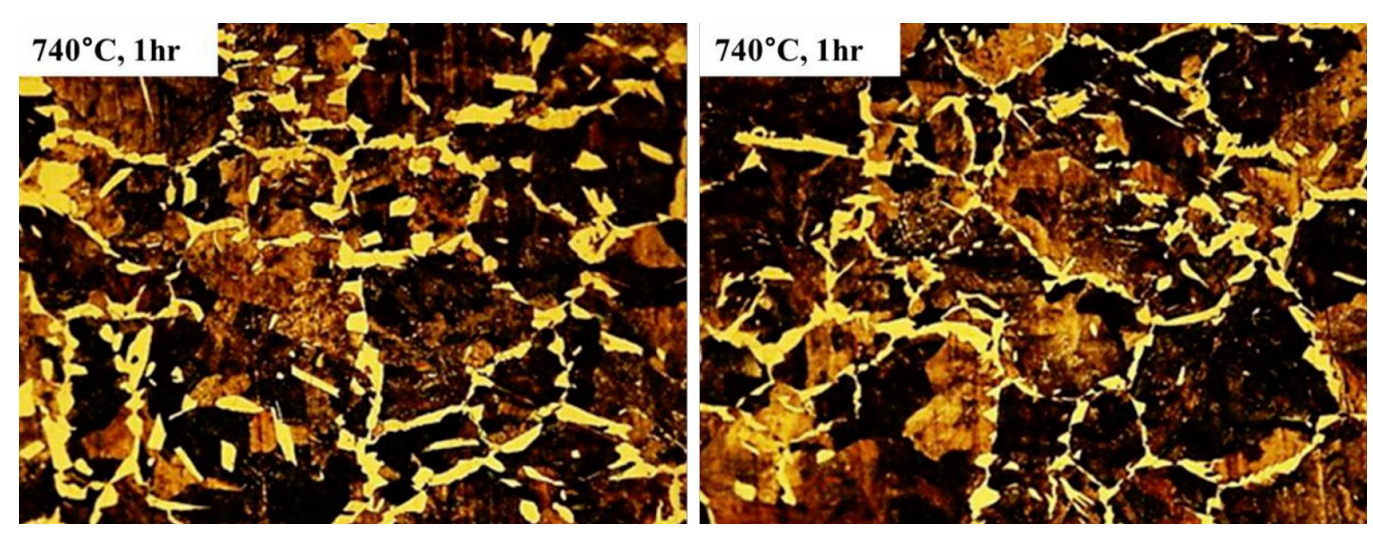

FIG. 4. OPTICAL MICROSCOPY OF SLOW HEATING RATE IN THE BOX FURNACE AT $740^{\circ} \mathrm{C}$ FOR 1 HOUR
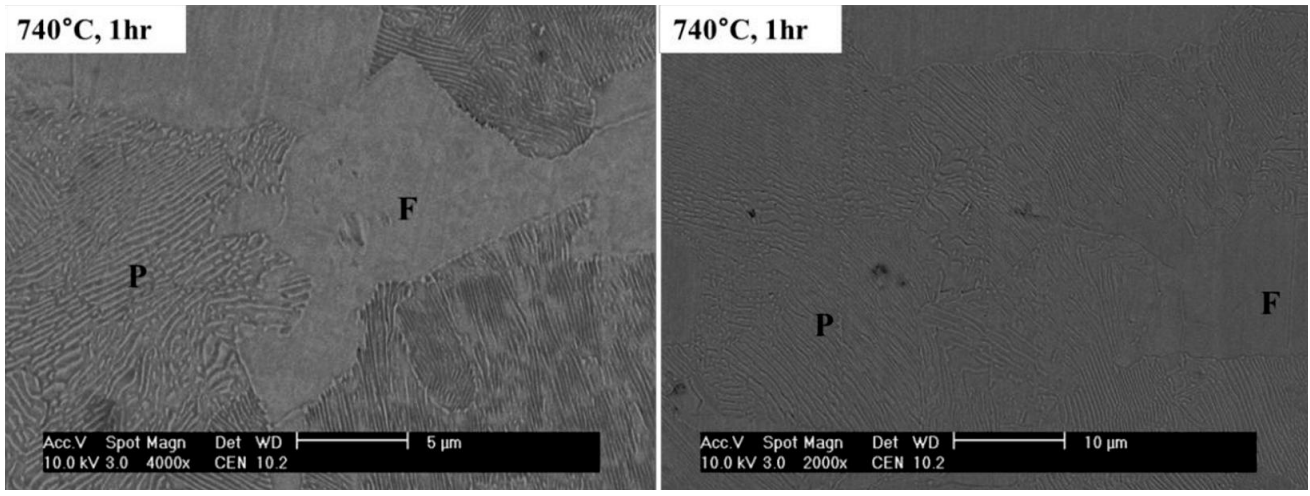

FIG. 5. SEM MICROSTRUCTURE OF SLOWLY HEATED STEEL IN BOX FURNACE AT $74^{\circ} \mathrm{C}$ FOR 1 HOUR

\section{CONCLUSION}

To observe the effect of heating rate on microstructural features upon phase transformation was investigated using the optical microscopy and scanning electron microscopy. The holding time for rapidly heated steel samples was $10 \mathrm{sec}$ in lead bath furnace, microstructural characteristics of that steel show that cementite plates in the pearlite phase dissolve by stimulating the austenite phase in a short period of holding on that temperature.

In the slowly heated steel samples, experimental investigation indicates that there is no any evidence for dissolving the cementite plates even at a longer holding time thus there is no any indication that cementite plates has transformed into austenite phase. The possible reason for this morphology is that in rapidly heating conditions there is no recrystallization takes place due to shorter time interval but in the slowly heating rates recrystallization may take place.

\section{ACKNOWLEDGEMENT}

Authors would like to thanks the Department of Materials Science \& Engineering, Korea, Advanced Institute of Science and Technology, and Department of Materials Engineering, NED University of Engineering \& Technology, Karachi, Pakistan, for experimental and financial support throughout this project.

\section{REFERENCES}

[1] Das, T., Li, J.Y., Painter, M., and Summerville, E., "Evaluation of Two AISI 4037, Cold Heading Quality Steel Wires for Improved Tool Life and Product Quality”, Journal of Materials Engineering \& Performance, Volume 11, No. 1, pp. 86-91, February, 2002. 
[2] Xiaoyu, M.A., Alan, O., Jim, H.-P., Hone, M., Nickoletopolulos, N., and John, J., "Effect of Microstructure on the Cold Headability of a Medium Carbon Steel", International Scientific Invention Journals, Volume 44, No. 5, pp. 905-913, 2004.

[3] Sabih, A., and Nemes, J.A.,"Internal Ductile Failure Mechanisms in Steel Cold Heading Process", Journal of Materials Processing Technology, Volume 209, No. 9, pp. 4292-4311, May 2009.

Brown, E.L. and Ardo, A.J., "Thermodynamical Processing of Micro Alloyed Austenite", Metallurgical Society of American Invitational Mathematics Examination, pp. 319-341; 1982.

[5] Kaspar, R., and Kapellner, W.,"The Influence of Thermomechanical Treatment on the Transformation Behaviour of Steels Steel Research", International, pp. 557-562. 1986.

[6] Savran, V.I., "Microstructural Features of Austenite Formation in C35 and C45 Alloys, Metallurgical and Materials Transactions-A, pp. 946-955, 2007.

Huang, J., "Austenite Formation During Intercritical Annealing",Metallurgical and Materials TransactionsA, pp. 3363-3375, 2004.

Wilson, F.G., "Aluminum Nitride in Steel", Journal of International Materials Reviews, Volume 33, pp.221-286, 1988 .

[9] Mohanty, R.R., "Effect of Heating Rate on the Austenite Formation in Low-Carbon High-Strength Steels Annealed in the Intercortical Region", Metallurgical and Materials Transactions-A, Volume 26, pp. 946-955, 2007.

[10] Bhadeshia, H., "The Effects of Alloying Elements on Iron-Carbon Alloys", Book of Steels, pp.71-93 2006.

[11] Reed, R.C., "Determination of Re-Austenitisation Kinetics in a $\mathrm{Fe}-0.4 \mathrm{C}$ Steel Using Dilatometry and Neutron Diffraction", Materials Science and Engineering Transactions-A, Volume 256, Nos. 1-2, pp. 152-165, November, 1998
[12] Oliveira, F.L.G., "Kinetics of Austenite Formation During Continuous Heating in Low Carbon Steel”, Materials Characterization, Volume 58, No. 3, pp. 256-261, March, 2007.

[13] Yahya, P., "Understanding the Effect of Aluminum on the Microstructure on Low Level Nitrogen Steel", Journal Materials Science and Technology, Volume 25, No. 10, pp. 1243-1248, 2009.

[14] Lim, N.S.,"Effects of Aluminum on the Microstructure and Phase Transformation of TRIP Steels", International Journal of Metals and Materials, Volume 18, No. 4, pp. 647-654, August, 2012.

[15] Bodnar, R.L., and Hasen, S.S., "Effects of Widmanstätten Ferrite on the Mechanical Properties of a 0.2 pct C- 0.7 pct Mn Steel", Metallurgical and Materials TransactionsA, Volume 25, No. 4, pp. 763-773 , 1994.

[16] Caballero, F.G., Bhadeshia, H.K.D.H., Mawella, K.J.A., and Jones, D.G., "Very Strong Low Temperature Bainite", Materials Science and Technology, pp. 279. 2002

[17] Karmakar, A., Sivaprasad, S., Kundu, S., and Chakrabarti, D., "Tensile Behavior of Ferrite-Carbide and FerriteMartensite Steels with Different Ferrite Grain Structures", Journal of Metallurgy Materials Transactions-A, pp. 1659-166445, 2014.

[18] Calcagnotto, M., and Ponge, D., "Orientation Gradients and Geometrically Necessary Dislocations in Ultrafine Grained Dual-Phase Steels Studied by 2D and 3D EBSD”, Materials Science Engineering, pp. 2738-2746.2010.

[19] Mazaheri, Y., and Kermanpur, A., "A Novel Route for Development of Ultrahigh Strength Dual Phase Steels", Materials Science Engineering-A, No. 619, pp. 1-11, 2014.

[20] Francis J.A., Bhadeshia, H.K.D.H., and Withers, P.J., "Welding Residual Stresses in Ferritic Power Plant Steels", Materials Science Technology, Volume 23. No. 9, pp. 1009, 2007. 
[21] Caballero, F.G., and Capdevila,C., "Modelling of Kinetics of Austenite Formation in Steels with Different Initial Microstructures", International Scientific Invention Journals, pp. 1093-1102, 2001.

[22] Oliveiraa, F.L.G., and Andrade, S., "Kinetics of Austenite Formation During Continuous Heating in a Low Carbon Steel", Journal of Materials Characterization, Volume 58, No. 3, pp. 256-261, March, 2007.
[23]

Huang, J., Poole, W., and Militzer, M., "Austenite Formation During Intercritical Annealing", Metallurgical and Materials Transactions-A, Volume 35, No. 11, pp. 3363-3375, November, 2004.

[24] Humphreys, F.J., and Hatherly, M., "Recrystallization and Related Annealing Phenomena", 1st Edition, Pergamon, pp. 127-71, New York, 1995.

[25] Mecozzi, J., Sietsma, S., and van der Zwaag, M., "Austenite Formation and Decomposition", ISS and TMS, pp. 353-66, Warrendale, PA, 2003. 